\title{
$\sum_{\text {Dิ }}^{\text {OD }} \frac{\mathrm{CPI}-360}{\mathrm{D} 4 \mathrm{D} 8}$
}

$\sum_{0}^{\text {OD }} \frac{\mathrm{CPI}-360}{\mathrm{D} 4 \mathrm{D} 8}$

Histone H3 blot

H3K27me3 blot 